\title{
Lieroistutus osana rakenteeltaan heikentyneen savimaan kunnostusta
}

Visa Nuutinen, Elise Ketoja, Mervi Nieminen ja Taisto Sirén

MTT (Maa-ja elintarviketalouden tutkimuskeskus),31600Jokioinen, etunimi.sukunimi@mtt.fi

\section{Tiivistelmä}

Tutkimme kahdella varsinais-suomalaisella pellolla mahdollisuutta liittää lierojen istuttaminen osaksi huonorakenteisen savimaan kunnostusta. Ennen istutusta pelloilla esiintyi hyvin vähän tai ei lainkaan lieroja. Vuotta ennen istutukseen ryhtymistä oli kummallakin pellolla otettu viljelykiertoon nurmi lierojen elinolosuhteita parantavana toimenpiteenä. Istutus tehtiin keväällä 2003 lieroja sisältäneen pintamaan pistemäisinä siirtoina koeruutuihin. Istutuskäsittelyjä oli kaksi. Toisessa käytettiin pelkkää istutusmaata, toisessa sen joukkoon lisättiin kartonkitehtaan jätekuitupohjaista ("0-kuitu") maanparannusvalmistetta lierojen suojaksi ja ravinnoksi. Lierojen runsastuminen oli selvästi nopeampaa istutuskäsittelyissä verrattuna kontrollimaahan, johon istutusta ei tehty. Yli seurantajakson (2003-2005) yhdistetyssä aineistossa lieroja oli eniten 0-kuituvalmistetta saaneissa ruuduissa, joissa istutuspisteissä mitattu tiheys oli keskimäärin 24 yksilöä $\mathrm{m}^{-2}$. Pelkkää istutusmaata saaneessa käsittelyssä tiheys oli $10 \mathrm{yks} . \mathrm{m}^{-2}$ ja kontrollissa 1 yks. $\mathrm{m}^{-2}$. Lierot alkoivat seurantajakson aikana levitä hitaasti peltoon. Pisimmillään ne olivat kahdessa vuodessa edenneet 2 m:n etäisyydelle istutuskohdasta. Istutuksilla saatiin lierojen runsastuminen peltolohkoilla käyntiin ja sikäli niitä voi pitää onnistuneina. Tiivistyneen savimaan huokoistamisen kannalta istutuksen hyödyt olivat kuitenkin tutkimuksen aikajänteellä pieniä johtuen lierojen varsin alhaisena pysyneestä tiheydestä ja hitaasta leviämisestä. Tulosten yleistettävyyttä vaikeuttaa istutusten ajoittuminen ennätyksellisen kuivalle sääjaksolle vuosina 2002-2003. Se todennäköisesti alensi lierojen tiheyttä istutusmaan lähdealueella sekä vaikeutti istutettujen lierojen kasvua ja lisääntymistä. Istutusmenetelmä osoittautui yksinkertaiseksi ja käytännön maanhoitotyöhön soveltuvaksi. Perusteltujen ja onnistuneiden lieroistutusten kannalta ratkaisevalta tekijältä vaikuttaa paikallisten olosuhteiden hyvä tuntemus. Vaikka motivaatiota ja mahdollisuuksia lieroistutuksen kaltaisen menetelmän käyttöönottoon voi epäillä, tulokset osoittavat, että lierojen aktiivinen hyödyntäminen on mahdollista osana maan rakenteen hoitoa ja ennallistamista.

Avainsanat: maan rakenne, maahuokoset, tiivistyminen, lierot, ennallistaminen, biodiversiteetti 


\section{Johdanto}

Maaperän rakenteen huononeminen on merkittävä peltoviljelyn taloudellista ja ekologista kestävyyttä heikentävä tekijä (Håkansson 2000). Etenkin pääviljelyalueemme saviseuduilla eteläisessä Suomessa maan tiivistymisongelmat ovat lisääntyneet raskaalla kalustolla tehtävän yksipuolisen viljanviljelyn myötä. Lierot ovat tärkeä tekijä viljeltyjen savien huokosrakenteen muodostumisessa (esim. Nuutinen 2000, Alakukku \& Teräväinen 2002). Kasvien juuret käyttävät lierojen käytäviä kulkureitteinään ja lisäksi vesi virtaa käytäviä pitkin maahan ja salaojiin (Pitkänen \& Nuutinen 1998, Shipitalo ym. 2004). Lierokantojen vahvistaminen onkin hyödyllinen tavoite rakenteeltaan huonontuneen maan ennallistamisen kannalta. Joissain tapauksissa maan perusparannustoimet sekä lieroja suosivat viljelytavat voivat riittää lierokantojen kasvuun saattamiseen. Silloin taas kun olosuhteiden huononeminen on johtanut lierojen paikalliseen sukupuuttoon ja etäisyys sopiviin lierojen lähdealueisiin on pitkä, saattaa lierojen istuttaminen peltoon olla muiden maanhoitotoimien ohella perusteltua kantojen kasvun nopeuttamiseksi (Halle \& Fattorini 2004). Tämän tutkimuksen tavoitteena oli selvittää, voidaanko lieroja istuttamalla olennaisesti nopeuttaa alentuneen lierokannan kasvua ja sitä kautta maan fysikaalisen laadun parantumista. Käytännöllisenä tavoitteena oli kehittää yksinkertainen tapa istuttaa lieroja peltomaahan ja tutkia samalla mahdollisuuksia hyödyntää puunjalostusteollisuuden jätekuitua lieroistutusten onnistumisen takaajana.

\section{Aineisto ja menetelmät}

Lierojen istutuskokeiden paikaksi valittiin kaksi Kuusjoella, Varsinais-Suomessa sijaitsevaa aitosavipeltoa (Pellot 1 ja 2), jotka olivat pitkään olleet pääasiassa viljanviljelyssä. Lohkojen viljelijät olivat havainneet pelloilla maan rakenteen heikkenemistä, mikä ilmeni $\mathrm{mm}$. sadeveden hitaana imeytymisenä sekä kasvien huonona kasvuna. Myös lierotiheys oli viljelijöiden muistikuvien perusteella alentunut. Maan rakenteen parantamiseksi pelloilla otettiin vuonna 2001 viljelykiertoon pitkäaikainen ruokonatanurmi, mitä voidaan pitää lierojen kannankasvua tukevana toimenpiteenä. Lierojen lähtötiheys määritettiin vähän ennen istutusta laskemalla lierot yhdestä maanäytteestä kussakin perustettavan istutuskokeen ruudussa. Pellolta 1 löytyi yksi peltoliero, Pellolta 2 lieroja ei löydetty lainkaan.

Keväällä 2003 tehtiin lierojen istutus lieropitoisen pintamaan siirtona. Lierojen lähdealueena käytettiin Jokioisissa sijainnutta runsaslieroista peltolohkoa, jonka muokkauskerros oli hietasavea. Käsittelyinä istutuskokeessa olivat: [1] ei lieroistutusta (=käsittelemätön kontrolli), [2] lieroistutus ja [3] lieroistutus + kartonkitehtaan jätekuidusta (0-kuitu) ja kananlannasta tuotettu "Pehtoorin Ehta" maanparannusvalmiste (Humuspehtoori Oy). Pellolla 1 lohkoja (=toistoja) oli neljä ja Pellolla 2 kolme (Kuva 1). Istutusruutuihin tehtiin kaivinkoneella yhdeksän istutuskuoppaa säännölliseen $3 \times 3$ hilaan, viiden metrin etäisyydelle toisistaan (Kuva 1). Kontrolliruutuihin ei kaivettu kuoppia, mutta niihin merkittiin vastaava 3 x 3 hila. Lieroistutusmaa kuljetettiin istutusruutuihin etukuormaajalla ja lapioitiin istutuskuoppiin. Käsittelyssä [2] kuoppiin lapioitiin vuorokerroksittain maata ja 0-kuituvalmistetta. Istutusmaasta otettujen näytteiden perusteella tiettyyn pisteeseen istutettujen lierojen määrä oli keskimäärin 10 yksilöä (min: 4, max: 18). Vaikka tämä lieromäärä oli korkea koelaueiden lähtötilanteisiin verrattuna, oli lierojen lähdealueen valinnassa tähdätty paljon korkeampaan istutustiheyteen.

Lierojen runsauden kehittymistä seurattiin kolmeen otteeseen, syksyllä 2003 sekä keväällä 2004 ja 2005. Jokaisessa näytteenotossa tutkittiin 3x3 -hilan keskimmäinen piste kaikissa koeruuduissa. Vuosina 2004 ja 2005 tutkittiin lisäksi yksi tai kaksi satunnaisesti valittua lisäpistettä, vastaavasti. Lierotiheys määritettiin lajittelemalla kentällä käsin muokkauskerroksesta otettu $20 \times 20 \times 15 \mathrm{~cm}^{3}$ suuruinen maanäyte.

Lierojen leviämistä istutuspisteistä tutkittiin keväällä 2004 ottamalla näyte 0.5 m:n etäisyydeltä jokaisen istutushilan keskipisteestä sekä yhdestä satunnaisesti valitusta pisteestä. Keväällä 2005 leviämistä tutkittiin valitsemalla kustakin istutusruudusta piste, jossa oli havaittu eniten lieroja keväällä 2004 ja/tai 2005. Sen ympäriltä 0.5 m:n etäisyydeltä otettiin 1-3 näytettä siten, että heti lieroja löydettäessä näytteenottoa jatkettiin kyseiseen suuntaan puolen metrin välein kunnes lieroja ei enää löytynyt.

Käsittelyjä verrattiin varianssianalyysillä, jossa käytettiin kunkin ruudun havaintona seurantajakson keskiarvoa neliömetrikohtaiselle lierotiheydelle. 


\section{Esimerkki koejärjestelystä (Pelto 2)}
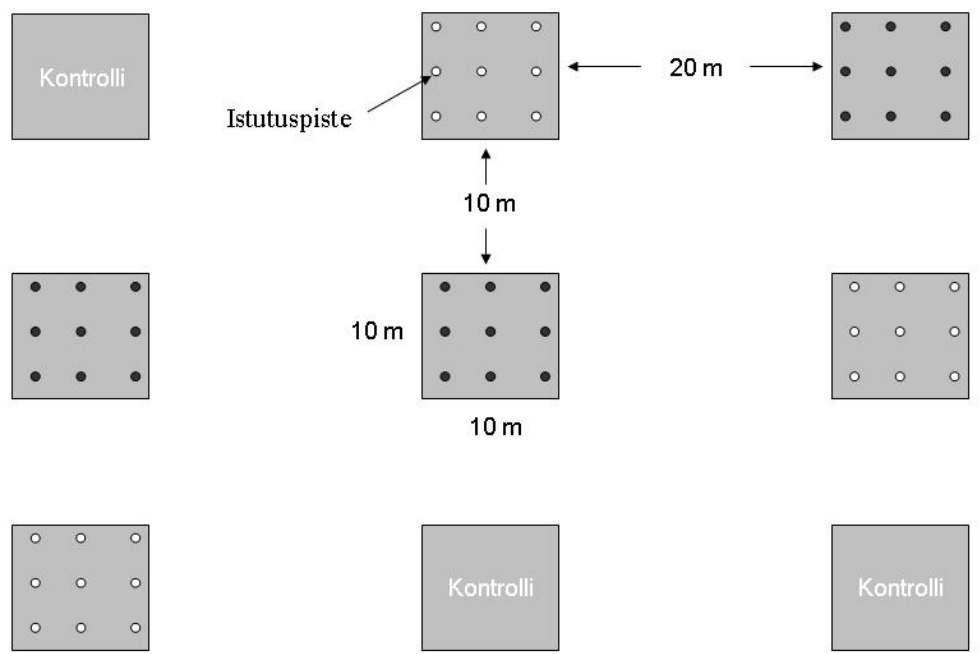

II

I

$\circ=$ Lieroistutus $\quad \bullet=$ Lieroistutus +0 -kuitu

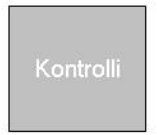

III

Kuva 1. Lierojen istutuskokeen koejärjestely Pellolla 2. Kokeen kolme lohkoa on merkitty roomalaisella numerolla.

\section{Tulokset ja tulosten tarkastelu}

Lierotiheydet olivat kummallakin koepellolla kaiken kaikkiaan varsin alhaisia (Taulukko 2). Istutusten onnistumista ilmeisesti rajoitti niiden ajoittuminen ennätyksellisen kuivalle sääjaksolle vuosina 2002-2003 (ks. Silander \& Järvinen 2004). Se todennäköisesti alensi lierojen tiheyttä lähdealueella sekä heikensi istutettujen lierojen kasvua ja lisääntymistä. Kummallakin koepellolla istutettu lierokanta kuitenkin selvisi hengissä istutusta seuranneen kesän 2003 kovista hellejaksoista ja ensimmäisestä seurantanäytteenotosta lähtien lieroja löydettiin säännönmukaisesti istutuspisteistä. Lierot olivat poikkeuksetta peltolieron kaltaisia pintamaan lieroja.

Molemmilla koepaikoilla lieroistutuksen tulokset olivat samansuuntaisia; kontrollia ja istutuskäsittelyjä verrattaessa lierotiheyden todettiin olevan huomattavasti korkeampi istutusruuduissa (Taulukot 1 ja 2). Korkein tiheys mitattiin 0-kuituvalmistetta saaneessa käsittelyssä, jossa keskimääräinen lierotiheys oli tilastollisesti merkitsevästi korkeampi kuin kontrollissa tai pelkässä istutuskäsittelyssä.

Taulukko 1. Testitulokset lierojen runsaudelle seurantajakson (2003-2005) aikana.

Vaihtelun lähde

Vapausasteet

F-arvo

P-arvo

Osoittaja Nimittäjä

\begin{tabular}{lcccl}
\hline Koepaikka & 1 & 15 & 0.21 & 0.65 \\
Käsittely & 2 & 15 & 5.75 & $0.01^{* *}$ \\
Koepaikka x Käsittely & 2 & 15 & 0.38 & 0.69 \\
& & & & \\
\hline
\end{tabular}

Kontrolliruuduissakin lieroja havaittiin, mutta vasta keväällä 2005. Pellolla 1 mitattiin yhden kontrolliruudun laidassa poikkeavan korkea lierotiheys, mikä saattoi olla seurausta lierojen leviämisestä viereisestä istutusruudusta. Pellolla 2 löydettiin lieroja yhdestä kontrolliruudusta läheltä 
kokeen reunaa. Yksilöt olivat pintakarikkeen tummia lieroja, jotka olivat mahdollisesti levinneet luontaisesti pellon piennaralueelta.

Taulukko 2. Lierotiheyksien keskiarvot ja keskarvojen luottamusvälit yli seurantajakson ja koepaikkojen. Samalla kirjaimella merkityt käsittelyt eivät poikkea toisistaan $5 \%$ :n riskitasolla.

\begin{tabular}{lllll} 
& Lieroja per $\mathrm{m}^{2}$ & \multicolumn{2}{c}{ Keskiarvon 95\%:n luottamusväli } \\
& & Yläraja & Alaraja & \\
\hline Ei istutusta (kontrolli) & 1 & 0 & 8 & a \\
Lieroistutus & 10 & 2 & 23 & $\mathbf{a}$ \\
Lieroistutus + 0-kuituvalmiste & 24 & 10 & 43 & b \\
\hline
\end{tabular}

Istutettujen lierojen luontaisesta lisääntymisestä koepelloilla kertoi keväästä 2004 lähtien istutuspisteistä löydetyt lierojen munakotelot ja keväällä 2005 munakoteloita esiintyi Pellolla 1 myös istutuspisteiden ulkopuolella.

Lierot alkoivat hitaasti levitä istutuspisteistä ympäröivään maahan. Pellolla 1 lieroja löytyi jo keväällä 20040.5 m:n etäisyydeltä istutuspisteistä ja runsastuminen istutuspisteen vieressä jatkui seuraavana vuonna (Kuva 2). Pellolla 2 ensimmäiset viitteet lierojen leviämisestä saatiin vasta vuonna 2005. Kummallakaan pellolla lierot eivät kevääseen 2005 mennessä olleet yleensä levinneet puolta metriä kauemmas istutuspisteestä. Kuitenkin yhdessä Pellon 1 pisteessä lierot olivat tuolloin levittäytyneet 2 m:n etäisyydelle istutuskohdasta. Lierojen leviämistä ympäröivään maahan hidastivat todennäköisesti sekä alhainen lierotiheys istutuspisteissä että hyvin vaativat olosuhteet ympäröivässä, tiivistyneessä savessa. Pellolla 2 lierojen leviämistä vaikeutti ilmeisesti poikkeuksellisen suurista kuivatusongelmista johtunut maan märkyys.

Näytteenottojen yhteydessä tehtyjen alustavien havaintojen perusteella lierot olivat alkaneet huokoistaa istutuspisteiden alapuolista maata. Pellon 1 alueella, jossa lierot olivat levinneet tehokkaimmin, voitiin pintamaassa nähdä merkkejä lierojen maata huokoistavasta vaikutuksesta.
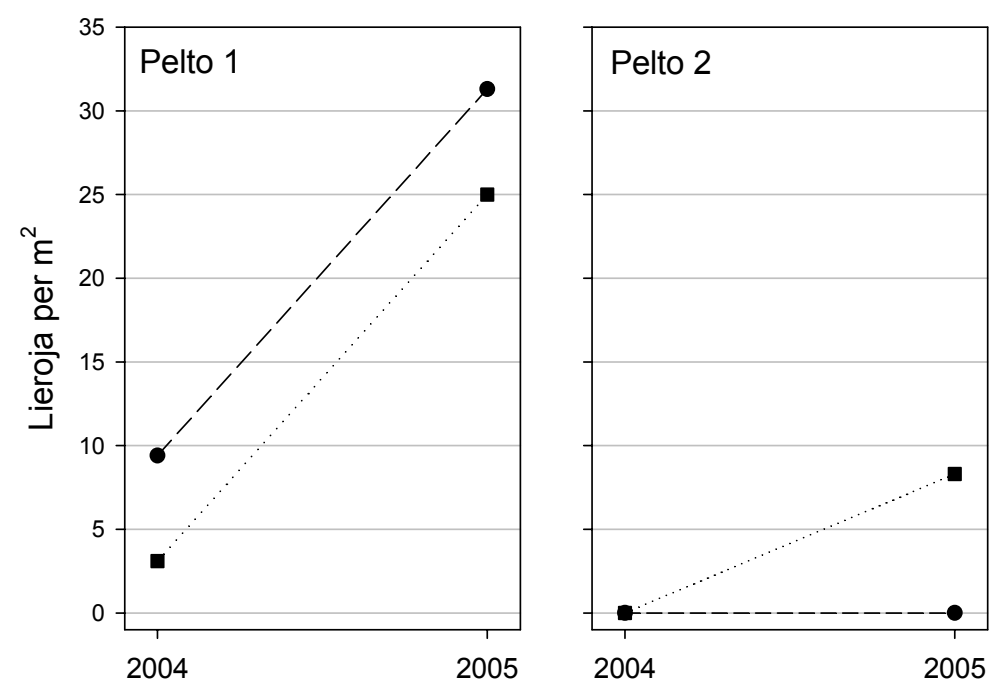

Aika

Kuva 2. Lierotiheydet puolen metrin etäisyydellä istutuspisteestä vuosina 2004 ja 2005 . Luvut ovat keskiarvoja. Neliö: lieroistutus; ympyrä: lieroistutus +0 -kuituvalmiste.

\section{Johtopäätökset}

Kokeen tulosten perusteella lierokannan aktiivinen hoito on mahdollista liittää osaksi huokosrakenteeltaan heikentyneen viljelymaan kunnostusta. Istutus oli edellytys lierojen 
runsastumiselle koepaikoilla, nurmen ottaminen viljelykiertoon ei siihen yksin riittänyt. Kaksi vuotta kokeen aloittamisen jälkeen lierojen levittäytyminen peltoon oli kuitenkin siinä määrin vähäistä, että tutkimuksen päätavoitteen - tiivistyneen saven huokoistamisen - kannalta istutuksella saavutetut hyödyt olivat kaikesta päätellen hyvin vähäisiä. Seurantajakson lyhyyden vuoksi istutustuloksen lopullinen arviointi ei kuitenkaan vielä ole mahdollista.

Lieroistutuksessa käytetyt työmenetelmät osoittautuivat yksinkertaisiksi ja toimiviksi. 0kuitupohjainen maanparannusvalmisteen lisääminen paransi istutuksen onnistumista. Aikaisemmassa Englannissa tehdyssä kenttätutkimuksessa havaittiin 0-kuidun lisäämisen maahan suosineen lieroja kuivana kasvukautena, ilmeisesti kuidun maan kosteutta säästäneen vaikutuksen vuoksi (Piearce ja Boone 1998). Sama seikka voi selittää Kuusjoen kokeiden tuloksen.

Vaikka mahdollisuuksia ja motivaatiota lieroistutuksen kaltaiseen epätavalliseen maanhoitotoimeen voikin epäillä, tulokset osoittavat, että lieroja voidaan aktiivisesti hyödyntää osana viljelymaan rakenteen hoitotoimia.

\section{Kiitokset}

Yhteistyöllään tutkimuksen onnistumista edesauttoivat Laura Alakukku, Antti Härri, Mika Äijälä, Raimo Kauppila, Sampsa Peltola, Reino Mantsinen ja Ilkka Sipilä. Kenttätyössä olivat apuna Marja-Liisa Westerlund, Matti Ylösmäki, Tiina Koivisto, Jussi Mäntylä, Juha Eeva, Sanna Niskanen ja Ilkka Sarikka.

\section{Kirjallisuus}

Alakukku L. \& Teräväinen, H. (toim.) 2002. Maan rakenteen hoito. ProAgria Maaseutukeskusten Liiton julkaisuja 982. Tieto tuottamaan $98.96 \mathrm{~s}$.

Halle, S. \& Fattorini, M. 2004. Advances in restoration ecology: insights from aquatic and terrestrial ecosystems. Sivut 10-33 Teoksessa: Temperton, V.M. ym. Assembly Rules and Restoration Ecology. Island Press, Washington.

Håkansson, I. 2000. Packning av åkermark vid maskindrift. Omfattning - Effekter - Motåtgärder. Rapporter från Jordbearbetningsavdelningen $\mathrm{Nr}$ 99. SLU, Uppsala. $123 \mathrm{~s}$.

Nuutinen, V. 2000. Läpi harmaan saven. Maatalouden tutkimuskeskuksen julkaisuja. Sarja A 79: 39-46.

Piearce, T.G. \& Boone, G.C. 1998. Responses of invertebrates to paper sludge application to soil. Applied Soil Ecology 9: 393-397

Pitkänen, J. \& Nuutinen, V. 1998. Earthworm contribution to infiltration and surface runoff after 15 years of different soil management. Applied Soil Ecology 9: 411-415.

Shipitalo M.J., Nuutinen V. \& Butt K.R. 2004. Interaction of earthworm burrows and cracks in a clayey, subsurface-drained, soil. Applied Soil Ecology 26, 3: 209-217.

Silander J \& Järvinen E.A. (toim.) 2004. Vuosien 2002-2003 poikkeuksellisen kuivuuden vaikutukset. Suomen ympäristö 731. Suomen ympäristökeskus. Edita Prima Oy, Helsinki. ISBN 952-11-1841-5. 